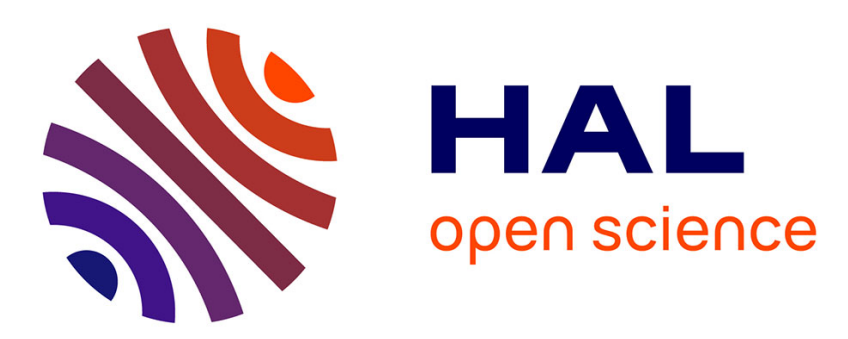

\title{
Recognizing heat-treated chert: A comparison between infrared spectroscopy and fracture surface analysis
}

\author{
Julie Bachellerie, Patrick Schmidt
}

\section{To cite this version:}

Julie Bachellerie, Patrick Schmidt. Recognizing heat-treated chert: A comparison between infrared spectroscopy and fracture surface analysis. Archaeometry, 2021, 64 (1), pp.39-58. 10.1111/arcm.12701. hal-03309596

\section{HAL Id: hal-03309596 https://hal.science/hal-03309596}

Submitted on 2 Aug 2021

HAL is a multi-disciplinary open access archive for the deposit and dissemination of scientific research documents, whether they are published or not. The documents may come from teaching and research institutions in France or abroad, or from public or private research centers.
L'archive ouverte pluridisciplinaire HAL, est destinée au dépôt et à la diffusion de documents scientifiques de niveau recherche, publiés ou non, émanant des établissements d'enseignement et de recherche français ou étrangers, des laboratoires publics ou privés. 


\title{
Recognizing heat-treated chert: A comparison between infrared spectroscopy and fracture surface analysis
}

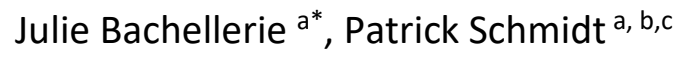

\author{
a TRACES - UMR5608, Université de Toulouse Jean-Jaurès, Maison De La Recherche, 5 Allée Antonio \\ Machado, 31058 TOULOUSE, France \\ ${ }^{b}$ Eberhard Karls University of Tübingen, Department of Early Prehistory and Quaternary Ecology, \\ Schloss Hohentübingen, 72070 Tübingen, Germany \\ ' Eberhard Karls University of Tübingen, Department of Geosciences, Applied Mineralogy, \\ Wilhelmstraße 56, 72074 Tübingen, Germany
}

\begin{abstract}
:
Heat treatment of lithic raw material is used for the first time in Europe in the Solutrean of the upper Paleolithic. The study of which heating technique was used by these groups requires analytical methods to understand and recognize the chemical and physical processes involved. Roughness measurements were tested as a tool for recognizing heat treatment and to compare them to infrared spectroscopy. We measure the surface topography of geological samples to observe its evolution as a function of heating and then compare the results with those obtained on Solutrean artefacts. We also measured ear infrared analyses was carried out for comparing the effectiveness of surface roughness measurements. This work complements our knowledge about the heating environment used by Solutrean groups by confirming the use of controlled heating. In addition, our roughness measurements provide promising results for the recognition of heat treatment through the quantification of the surface luster.
\end{abstract}

Key-word: Silica rocks; Flint; Pyrotechnology; feuilles de laurier; laurel leaf; Fracture surface analysis; surface luster

\section{Introduction}

Heat treatment is a process that causes mechanical changes in rocks. It leads to an improvement of silica rocks' knapping quality and of the sharpness of cutting edges (see among others, Crabtree and Butler 1964; Purdy and Brooks 1971; Collins and Fenwick 1974; Flenniken and Garrison 1975; Anderson 1978; Domanski and Webb 1992; Torchy 2013; Key et al 2020, Schmidt et al 2019).

For a detailed overview of stone heat treatment in the World, see Schmidt 2020. The earliest archaeological evidence seems to date back to the Middle Stone Age (MSA) with the heat treatment of silcrete (Brown et al., 2009; Schmidt et al, 2020). Heat treatment is also documented in several other chrono-cultural contexts (see for example: Wilke et al. 1991; Lechevalier and Inizan 1996; Gibaja and Clemente 1997; Domanski et al. 2009; Lea et al. 2012; Schmidt and Hiscock 2020). In Europe, heat treatment is first used during the Upper Paleolithic Solutrean culture (circa 23.5-25.5 ka cal BP). The first recognition of intentional heating, in the context of Solutrean bifacial shaping sequences, dates back to the 1960-1970s (Bordes 1967; 1969; Collins 1973; Inizan et al. 1976). Recent studies have refined our knowledge on Solutrean heat treatment (Schmidt and Morala 2018; Schmidt et al. 2018; 
Schmidt and Morala 2020; Bachellerie et al. 2019). These new data suggest that Solutrean knappers used a standardized heating technique, which aimed at creating a heating environment allowing temperature control. However, the exact heating technique remains unknown.

One of the first issues encountered when studying heat treatment is its recognition in assemblages. Heating can lead to several visual changes of the rock surface, like reddening, surface whitening or potlid fracturing (Purdy and Brooks 1971; Masson 1981; Schindler et al. 1982; Domanski and Webb 1992; Tiffagom 2006). Unfortunately, both of these visible alterations are not systematic in all types of rocks. They may also be caused by post-depositional heating and are therefore unreliable for identifying intentional heating. The only way to make statements on whether the heat treatment was intentional is by finding out whether the knapping process continued after heating (i.e. whether the heating event was situated within the chaine opératoire). Such post-heat treatment knapping results in the appearance of a glossy or shiny aspect of fresh removal scars (see among others Crabtree and Butler 1964; Purdy and Brooks 1971; Inizan et al. 1976; Masson 1981; Domanski and Webb 1992). This surface gloss is caused by smoother postheating fracture surfaces, which, in turn, are a result of the transformation of the rock's fracture mechanics (Schmidt et al. 2019). Gloss intensity varies as a function of heating temperature and is different in different silica rock types (Bachellerie and Schmidt 2020). When associated with matt preheating surfaces, such glossy postheating surfaces are the only reliable macroscopic proxy for the recognition of intentional heat treatment (Inizan et al. 1976; Tiffagom 1998). Thus, without such gloss contrast (i.e. the presence of matt and shiny fracture scars on a single artefact, the latter crosscutting the former - in a lithic technological sense), it is not a straightforward process in identifying intentional heat treatment.

The heating history of chert artefacts, without making statements on intentionality, can be investigated through physical and chemical approaches. Several analytical techniques have been developed to do this (see for example: Melcher and Zimmermann 1977; Toyoda et al 1993; Borraldie et al. 1993, Santaniello et al. 2021). Near infrared spectroscopy (IR) is today the most often used method to investigate the heat treatment of artefacts (Schmidt et al. 2013; Santaniello et al. 2015; Schmidt et al. 2017; Bachellerie and Schmidt 2019; for a similar related approach see: Weiner et al. 2015). The technique is based on the structural changes of silica rocks that lead to progressive reduction of intergranular pores. This method allows the recognition of heated artefacts but also of the temperatures to which the rock has been subjected (e.g. Schmidt and Morala 2018; Schmidt et al 2017). The technique requires geological reference materials for temperature measurement. There are, however, some limitations to this method, one being that thicker stone artefacts (more than $5 \mathrm{~mm}$ ) cannot easily be analyzed in this way because they are opaque to IR radiation (because IR absorbance is measured by transmission through the artefacts). Generally, signal to noise ratio is problematic for thick artefacts and artefacts made from opaque chert varieties. The most important caveat is that this method cannot distinguish between intentional and post-depositional heating when it is not associated with other macroscopic analyses of surface gloss (Bachellerie et al. 2019).

Other studies have shown the potential of roughness measurements for heat treatment studies (e.g. Schmidt 2019; Bachellerie and Schmidt 2020). Surface gloss, observable on postheating removal scars, results from changes in the surface's micro-relief (Schmidt et al. 2019). Roughness measurements thus make it possible to study the evolution of such gloss and its intensity variations.

Preliminary results obtained on some cherts from southwestern France (Bergerac chert, Senonian chert, upper and Lower Turonian chert) have confirmed the evolution of surface roughness values as a function of heating temperatures (Bachellerie and Schmidt 2020). These results suggested that gloss 
intensity gradually increases upon heating in these silica rocks, suggesting that they were caused by the structural modifications occurring (see Schmidt et al. 2011). These data highlight the potential of roughness measurements for using surface gloss measurements to recognize heat-treated chert in archaeological assemblages objectively.

The aim of this study is therefore to apply microscopic roughness measurements as a tool for the recognition of heat treatment on stone artefacts from two Solutrean sites: Laugerie-Haute and Landry. For that purpose, we decided to work on a single type of rock to minimize variation and better understand the outcome, Bergerac chert. Preliminary analysis had already provided encouraging results on this material for roughness measurements (Bachellerie and Schmidt 2020). In addition to roughness analyses, we conduct IR analyses on Bergerac chert reference samples. This allows us to compare structural changes that occur during heating and fracture mechanics modifications in the same rocks.

Two sets of analyses were then carried out in 2019 and 2020. In addition to geological reference collections, Solutrean artefacts were also analyzed in order to test the efficiency of these methods and to enrich our knowledge of the heating technique used by the Solutreans. Our IR analyses were conducted in 2019 on Solutrean artefacts from the National Museum of Prehistory of France. Unfortunately, this material had been returned before our roughness measurements tests in 2020 .

\section{Material and methods}

\section{Geological samples}

Only Bergerac chert was selected for this study: a marine chert of Campanian $V$ age, easily identifiable by its colorations and its zonal aspect. Regularly exploited by Solutrean groups, and often found in upper Paleolithic contexts in general (Fernandes et al 2012), this chert is often described as having good knapping quality (Turq 2000; Turq and Morala 2013; Delvigne 2016; Morala 2017). It is almost exclusively located around the city of Bergerac (Dordogne).

Seven blocks of Bergerac chert from three different outcrops were used to make a reference collection of unheated and experimentally heat-treated flakes. We used three of these blocks for roughness measurements (table S1) and four for IR analyses (table S2). These blocks come from three different Bergerac chert deposits. Their coloration varies clearly (from yellow to violet, grey or blue, with different zonation) as well as their knapping quality.

Despite a rather slow temperature rise, the heated blocks sometimes showed signs of overheating. From $300^{\circ} \mathrm{C}$, pot lids sometimes appeared, although not inhibiting the knapping. At 350 and $400^{\circ} \mathrm{C}$, we sometimes observed crazing and cracking. One block explode at $400^{\circ} \mathrm{C}$, thus no flakes could be removed from block $\mathrm{C}$ after heating to this temperature. The intensity of reddening varies from one block to another but is globally significant from $300^{\circ} \mathrm{C}$

\section{Archaeological samples}

Archaeological samples come from two sites: Laugerie-Haute West and Landry. Laugerie-Haute West is a rock shelter located about $2 \mathrm{~km}$ from the town of Les Eyzies de Tayac in Dordogne. It is a key site discovered by Lartet and Christy in 1863, excavated by Denis and Elie Peyrony and then François Bordes during the $20^{\text {th }}$ century. These excavations yielded a large quantity of upper Paleolithic materials and a long stratigraphic sequence of 5-6 meters thick. The stratigraphy approximately covers the period 
from 28 to $19 \mathrm{ka}$ cal BP and all the Solutrean phases are represented. A large amount of bifacial tools, especially laurel-leaf points, were discovered (Smith 1966).

The site of Landry was excavated more recently in 2011-2012. It is an open-air site with one Upper Solutrean level well preserved across $300 \mathrm{~m}^{2}$. More than 12000 lithic artefacts were excavated, including more than one hundred bifacial tools and shouldered points. The site showed an organization with specialized activity zones reflecting different degrees of technical knowledge (Brenet et al. 2018).

Macroscopic inspections were made on the Solutrean lithic vestiges of both sites to detect heattreated material on the basis of gloss contrast. For our infrared analyses, fifteen artefacts made from Bergerac chert were selected: four without any evidence of heating, eight clearly heat-treated with gloss contrast, and three tools with unclear signs of heat-treatment (table 3 ). These artefacts are mostly laurel-leaf fragments, but also some fragments of shouldered points and scrapers (Fig. 1). In Landry, there are no laurel leaves in Bergerac chert, so we choose to analyze two scrapers without macroscopic indications of heat treatment.

For surface measurements, our geological calibration series was compared to fourteen other artefacts made from Bergerac chert (mostly laurel-leaf points), previously examined by Schmidt and Morala (2020). IR analyses carried out on these pieces provided conclusive results. On the other hand, the surface roughness measurements that had been performed did not yield consistent results, in the sense that heat treatment could not be recognized based on the measurements (Schmidt and Morala 2020, but also see table 4).

Except for one scraper $\left(n^{\circ} 330\right.$; fig. $\left.1 n^{\circ} 2\right)$ coming from layer 9 of the Bordes excavations, the rest of the material is from the Peyrony or Hauser excavations. It comes from levels H" (Solutrean with laurel leaves) or H"' (Solutrean with shouldered points) that D. Peyrony was not always able to distinguish during excavation (Smith 1966). With regard to the current state of the Peyrony collection, we can only affirm that this material is coming from recent Solutrean levels (middle and upper Solutrean).

\section{Near Infrared spectroscopy (NIR)}

The theoretical background and detailed experimental set-up are explained in Schmidt et al. (2013). Only those details are presented here that are needed for understanding the method. Transformations of silica rocks upon heating are caused by the gradual disappearance of silanols ( $\mathrm{SiOH}$ ). It leads to the formation of new Si-O-Si bonds resulting in a progressive loss of open porosity. This chemical reaction corresponds to a "homogenization" of the mechanical properties (Schmidt et al. 2013).

We can trace these transformations through the average force of hydrogen bonds using near infrared (IR) spectroscopy. The analyses rely on the measurements of the transmission of near IR rays directly through the thin part of lithic samples. These measurements results in an absorption spectrum with a combination band towards $4,300-4,600 \mathrm{~cm}^{-1}$ caused by silanol groups. The $\mathrm{SiOH}$ band shape is measured as the ratio between the linear absorbance at $4545 \mathrm{~cm}^{-1}$ and $4469 \mathrm{~cm}^{-1}\left(4545 / 4469 \mathrm{~cm}^{-1}\right.$ ratio). This ratio is partly influenced by the quantity of water held in the intergranular porosity of chert samples due to the chemical interaction of pore water with surface $\mathrm{SiOH}$ (hydrogen bonding). The band's shape therefore indirectly measures the quantity of water in the network of open porosity and, if all available pore space is completely filled with water, also of the volume of the open pore space of the sample itself. More pore-water causes a shift to lower frequencies, while less pore-water causes a relatively larger band-component at higher wavenumbers (Schmidt et al. 2011). With heat-treatment, the volume of this open pore space gradually decreases (Roqué-Rosell et al. 2011; Schmidt et al. 2012; Milot et al. 2017). Schmidt et al.'s (2013) method aims at detecting past heating through the measurement of a sample's pore space with respect to the pore space of another sample of the same 
chert type that was never heated. The comparison of these two samples (the reference and the tested artefact) must have been subjected to the same protocol for filling their open porosity (with deionized or distilled water). If the tested sample produced a higher value of $4545 / 4469 \mathrm{~cm}^{-1}$ ratio, as compared with the same ratio for the reference sample, it indicates that the former was subjected to heating in the past.

Heating temperature can then be estimated by associating these measurements with measurements of experimentally heat-treated reference samples of the same chert. Several reference samples are experimentally heated to different temperatures ranges, rehydrated with the same protocol and then analysed for its $4545 / 4469 \mathrm{~cm}^{-1}$ ratio after each temperature steps. By comparing the ratio values of the archaeological samples to those of the reference pieces, the temperature ranges to which the archaeological material was subjected can be estimated. .

To establish a calibration series, 30 thin flakes were produced from each of the four geological blocks ( $n=120$ flakes). Twenty unheated flakes were kept at room temperature and the rest was heated in an electrical furnace: totaling in twenty flakes from all blocks per temperature step (at 200, 250, 300, 350 and $400^{\circ} \mathrm{C}$; table S2). Before this heating stage, flakes were dehydrated during $24 \mathrm{~h}$ at $110^{\circ} \mathrm{C}$ in a drying oven, and then hydrated in deionized water for $48 \mathrm{~h}$. Heating experiments were carried out in an electric furnace, in order to control temperature, time and speed of the heating process $\left(<1^{\circ} \mathrm{C} / \mathrm{min}\right)$. For structural and crystallographic modifications to be complete, samples were maintained during $2 \mathrm{~h}$ at maximum temperatures (for justification of this time, see: Schmidt et al. 2016). Before spectra were recorded on unheated reference samples, they were also dehydrated at $110^{\circ} \mathrm{C}$ during one day and then rehydrated in deionized water for $48 \mathrm{~h}$. To compare results between geological calibration samples and archaeological samples, Solutrean artefacts were also dehydrated during $24 \mathrm{~h}$ at $110^{\circ} \mathrm{C}$ in the same drying oven, and then rehydrated in deionized water for $48 \mathrm{~h}$.

All samples were analysed with an Agilent Cary 660 infrared spectrometer equipped with a DTGS detector at Tübingen University. Spectra were recorded between $7000-2000 \mathrm{~cm}^{-1}$ with a resolution of $8 \mathrm{~cm}^{-1}$. The analysis area was cut by a circular diagram with a diameter of $8 \mathrm{~mm}$. After fixing the samples in the spectrometer analysis chamber, the infrared radiation was directly transmitted through the thinnest parts of the samples. The measurement error was estimate to a fixed ratio of \pm 0.01 taken from previous studies (Schmidt et al. 2013; Schmidt and Morala 2018) and can most likely be explained by the heterogeneities in chert.

\section{Laser scanning microscope (LSM) analysis}

To observe the evolution of surface roughness as a function of heating, a reference collection of unheated and experimentally heat-treated flakes of Bergerac chert was made. Before the first heating step at $200^{\circ} \mathrm{C}$, five flakes were removed from each of the three unheated blocks. Then, we successively heat-treated all blocks in an electric furnace at $200,250,300,350$ and $400^{\circ} \mathrm{C}$. Flakes were removed from each block after each temperature step. To limit heat-fractures we chose a slow ramp rate $(\approx 0.6 / \mathrm{min})$. Blocks were maintained at maximum temperatures during $2 \mathrm{~h}$ (for justification see Schmidt et al. 2016) and then let to cool to room temperature during approximately $12 \mathrm{~h}$. Nodules all fractured at $400^{\circ} \mathrm{C}$ and block $\mathrm{C}$ exploded, precluding further flakes removal, and effectively ending the experiment.

After each heating step, five flakes were knapped from each nodule. This corresponds to thirty flakes per block (except for block $\mathrm{C}$ which exploded at $400^{\circ} \mathrm{C}$ ). In total, we produced 85 unheated and experimentally heated flakes using organic and soft-stone hammer percussion (table S1). They are mostly thin flakes ( $<5 \mathrm{~mm}$ thick). Roughness measurements were conducted on the flakes ventral faces using a laser scanning microscope (LSM) Keyence VK-100 at the Competence Center Archaeometry - Baden-Wuerttemberg (CCA-BW) at Tübingen University's Department of Geosciences 
(aided by C. Berthold and K.G. Nickel). These analyses allow the acquisition of 3D models of the sample surface without direct contact. We then extracted volume and roughness parameters from this model. Using a 50x objective, we produced 3D models from nine tiles, that were stitch together for each sample, over a $740 \mu \mathrm{m}$ by $540 \mu \mathrm{m}$ larger field of view.

We used the Gwyddion software package to process the 3D models. Figure 2 shows examples of 3D surface models obtained on the ventral face of four flakes: one not heated (fig. 2.a) and the other three experimentally heated to $200^{\circ} \mathrm{C}$ (fig. 2.b.), $300^{\circ} \mathrm{C}$ (fig. 2.c.) and $400^{\circ} \mathrm{C}$ (fig. 2.d.). We corrected the 3D models for inclination before measuring the arithmetical mean roughness $(\mathrm{Ra}$,$) from five linear profiles$ positioned at different spots within the surface model. Each profile (measuring between 0.2 and 0.3 $\mathrm{mm}$ in length) was arbitrarily placed and oriented, avoiding sample edges, pits and protruding features.

All Ra measurements were made using a cut-off filter of $0.15 \mu \mathrm{m}$ to exclude the waviness of the surfaces. This means that baselines for the Ra measurements were straight lines between every 0.15 $\mu \mathrm{m}$ on the profile. Vertical distances of each point are then measured above this baseline. This cut-off value was chosen based on previous results (Bachellerie and Schmidt 2020). Ra values obtained from geological samples are presented table S1.

The same treatment was performed on fourteen artefacts previously analyzed (see Schmidt and Morala 2020; table 4) which allows a re-evaluation of the first roughness data established on these pieces. For these tools, Ra measurements were conducted on removal scars and, for pieces with gloss contrast, on glossy removal scars. Contrary to what was described in the Materials and Methods section of Schmidt and Morala (2020), LSM data were acquired with a 50x objective (the paper wrongly reports the use of a 20x objective). Therefore, the inclusion of the 3D surface models from this earlier study in our analyses was possible by re-analysing them with our measurement protocol.

\section{Results}

\section{IR spectroscopic analyses}

IR results are presented in Table S2 (geological samples) and Table 3 (archaeological samples) and the overall results are summarized in Figure 3.

\section{Reference samples}

Hydration ratio values increase progressively with heating temperatures because the $\mathrm{SiOH}$ absorption band shifts to higher wavelengths. The band shape begins to evolve from $200^{\circ} \mathrm{C}$ upward, but the boxplots overlap significantly until $350^{\circ} \mathrm{C}$. Above $400^{\circ} \mathrm{C}$, the hydration ratios are significantly higher than the unheated values. For unheated reference samples, the median is 0.84 with standard deviations ranging from 0.80 to 0.91 . It is only from $350-400^{\circ} \mathrm{C}$ that the median of the values rises above these values.

\section{Archaeological samples}

Hydration ratio values of all archaeological samples are below 0.90 . Unheated and heat-treated samples (with gloss contrast) are not clearly differentiated by this analysis. Three ratio values of samples without macroscopic heating traces are consistent with unheated geological samples, another one with reference samples heated to $300^{\circ} \mathrm{C}$.

Ratio values of "test" samples (with ambiguous macroscopic indicators of heat treatment) are less than 0.9. Thus, no conclusions can be drawn on these pieces. For the samples with gloss contrast, values are between 0.82 and 0.89 . Comparing these hydration ratios to our geological calibration series allows estimating the heating temperature of the artefacts to around 250 and $350^{\circ} \mathrm{C}$. 


\section{Surface roughness measurements}

\section{Reference collection}

Roughness values obtained on the geological material are shown in Table S2. They are graphically represented as boxplots in Figure 4 (a). A progressive reduction of roughness is observed from $200^{\circ} \mathrm{C}$ onwards, being progressive up to $300^{\circ} \mathrm{C}$. Above $300^{\circ} \mathrm{C}$, roughness values remain the same. Dispersion of the values is important but tends to be lower at higher temperatures. Values of the unheated samples plot between 111 and $273 \mathrm{~nm}$. Despite partial overlapping of the values, samples with roughness values below $110 \mathrm{~nm}$ plot outside of the lower range of values measured on unheated samples, thus, they can be recognized as having a smoothened surface (the equivalent to macroscopically observable gloss) caused by heat treatment.

\section{Archaeological samples}

The results obtained on the archaeological material from Laugerie-Haute West are summarized in Table 4 and compared to the reference series in Figure 4 (b). Each piece is represented by the average of the five roughness measurements and the error bars correspond to their ranges. One of the two pieces without macroscopic heating traces yielded a relatively low roughness value $(89 \mathrm{~nm}$ on average), only partially overlapping the values of unheated geological samples. The three pieces with gloss contrast are distinguished by their low roughness values ( $90-50 \mathrm{~nm})$ which, according to our experimental reference samples, require heating to temperatures between 250 and $350^{\circ} \mathrm{C}$. Concerning the "test" pieces with unclear macroscopic traces of heating, two appear to be unheated and one heated to $\sim 300^{\circ} \mathrm{C}$. For the six others, measurements indicate a surface roughness between 90 and 130 $\mathrm{nm}$ corresponding to the standard deviations of the reference measurements at $30^{\circ} \mathrm{C}$ and $300^{\circ} \mathrm{C}$. We cannot conclude with certainty on their heating history.

\section{Discussion}

\section{Roughness and IR data}

IR analyses carried out on geological and archaeological samples partly confirm our initial hypotheses based on macroscopic observation. The evolution of the IR calibration curve indicates that structural transformations of the rocks occur from $200-250^{\circ} \mathrm{C}$, but the shape of the absorption band remains similar up to $350^{\circ} \mathrm{C}$. The hydration ratios obtained on unheated artefacts are consistent with these results, but overlapping of the data does not allow us to make inferences for the "test" pieces. For heat-treated archaeological samples $(n=8)$, the values produced are homogeneous, indicating that they were heated between 250 and $350^{\circ} \mathrm{C}$.

Results obtained by laser-scanning microscopy on geological samples indicate a gradual reduction in surface roughness from $200^{\circ} \mathrm{C}$ onwards. At higher temperatures, fracture surface is smoother, leading to the appearance of macroscopic heating gloss that we noted during the experiments. It appears most intense at $300-350^{\circ} \mathrm{C}$. This might also coincide with the improvement in the chert knapping qualities (see for example: Schmidt et al. 2012; Schmidt et al. 2019). At $400^{\circ} \mathrm{C}$, roughness increases slightly, which might be explained by the formation of internal micro-fractures caused by overheating of the rock (Schmidt 2014). For the archaeological corpus, our roughness data partially sustains our macroscopic observations. Pieces with gloss contrast have roughness values lower than the rest of the studied assemblage, indicating heat treatment above $300^{\circ} \mathrm{C}$. These results are in agreement with IR studies previously carried out on these same artefacts, which estimated a heating temperature 
between 250 and $350^{\circ} \mathrm{C}$ for these pieces (Schmidt and Morala 2018). However, a discrepancy between the results can be observed in several cases (see table 4). Particularly for one of the two macroscopically unheated artefacts: roughness measurements obtained on sample $n^{\circ} 46$ are on average lower than the values of our unheated geological referential. Contrary to this, the IR data obtained from this piece support the absence of heating on this tool. One possibility to explain this discrepancy would be that this sample was made from a Bergerac flint more homogeneous than our three geological reference blocks. Knapping quality of the Bergerac flint can vary significantly according to the deposits of raw material (Turq 200; Turq and Morala 2013). A larger geological reference series made from Bergerac chert from different outcrops might help in grasping these differences in the future. Another factor of uncertainty is that the conservation of the archaeological material (postdepositional movements and museum conservation for example) might have modified its surface, and in particular the pieces' roughness. This hypothesis should be tested in future work.

Are IR and surface roughness analysis complementary?

Calibration curves made from Bergerac reference samples provide encouraging results for the study of heat treatment of silica rocks in archaeological context. The structural transformations of the chert are initiated from $200^{\circ} \mathrm{C}$ onwards according to our IR data. However, only at higher temperatures (around $350^{\circ} \mathrm{C}$ ) does the hydration ratio increases more significantly. This limits the recognition of low temperatures heating $\left(200-350^{\circ} \mathrm{C}\right)$ for artefacts made from Bergerac chert that show no clear macroscopic traces related to heat treatment. This is the case here, where no conclusions could be drawn for some of the test samples.

On the other hand, roughness measurements obtained on reference material appear to be more sensitive to low temperature heating. The observed fracture patterns clearly evolve from $200^{\circ} \mathrm{C}$ on and stabilize at $300^{\circ} \mathrm{C}$. This makes it easier to recognize heating at lower temperatures when macroscopic proxies are not sufficient. Roughness measurements also allow to make direct inferences on the presence of heating gloss and thus of intentional heat treatment. IR and roughness measurement can therefore be considered to complement each other, both for the recognition of heating in archaeological context and also for its quantification.

\section{The heating technique used by Solutrean groups}

IR and roughness analyses gave similar results on the heating temperatures used by Solutreans. They also concur with previous studies on translucent Tertiary chert artefacts from Laugerie-Haute West (Schmidt and Morala 2018), and also from the site of Le Piage (Lot) (Bachellerie et al. 2019). On these two types of chert (Bergerac chert and Tertiary chert) Solutrean knappers would have heat-treated at temperatures between $250^{\circ} \mathrm{C}$ and $350^{\circ} \mathrm{C}$. This consistent temperature signal observed at several Solutrean sites suggests a specific management of the heating environment and strongly pleads against opportunistic heating in open-air fires (like in Schmidt et al. 2017).

According to the results of our LSM analyses, it is also around $300^{\circ} \mathrm{C}$ that the fracture surface roughness is the lowest and therefore the heating gloss the most intense. This requires the control of the heating environment by Solutrean flint knappers in order to allow the flint to be heated to these "optimal temperatures" to improve the mechanical properties of the material. Solutrean heat treatment, thus, was a technical process producing a material with better knapping quality that implies important technical and economic constraints. 


\section{Conclusion}

Our study provides new data on the knowledge of the heat treatment method used by Solutrean groups in the Southwest of France. It appears more and more clearly today, that Solutrean heat treatment was a process conducted in a controlled heating environment, at least at Laugerie Haute, Le Piage and Landry. The multiplication of studies on Solutrean heating environment suggests the mastery of this process by Solutrean groups who heat-treated certain bifacial tools between 200 and $400^{\circ} \mathrm{C}$. This work also highlights the potential of roughness analyses for the study of the heat treatment of chert. By making it possible to quantify the intensity of the heating gloss through the measurement of surface roughness that causes the gloss. This type of analysis has the potential to recognize heat treatment when macroscopic indices of heating are not sufficient. Our results are consistent with those obtained by IR spectroscopy and show a good complementarity application of the two types of analysis. The results of this study encourage us to further study surface roughness on other chert types and also to enrich our geological reference series.

\section{Acknowledgements}

We thank K.G Nickel and C. Berthold for their support of our LSM analyses. PS received financial support from the Deutsche Forschungsgemeinschaft (DFG) (grant number SCHM 3275/3-1).

We confirm that the data supporting the findings of this study are available within the online version of the article.

\section{REFERENCES}

Anderson, D. C. (1978). Aboriginal Use of Tongue River Silica in Northwest lowa. Plains Anthropologist, 23(80), 149-157. https://doi.org/10.1080/2052546.1978.11908888

Bachellerie, J., Renard, C., \& Schmidt, P. (2019). Technical innovations during the recent Solutrean in the southwest of France: Recognition of heat treatment of chert and estimation of heating temperatures based on the example of Le Piage (Lot, France). Journal of Archaeological Science: Reports, 27, 102001. https://doi.org/10.1016/j.jasrep.2019.102001

Bachellerie, J., \& Schmidt, P. (2020). First Results on Understanding the Shiny Surfaces of HeatTreated Chert. Lithic Technology, 45(4), 240-246. https://doi.org/10.1080/01977261.2020.1782590

Bordes, F. (1967). Considérations sur la typologie et les techniques dans le Paléolithique. Quartar, pl. I-VIII, 25-55.

Bordes, F. (1969). Traitement thermique du silex au Solutréen. Bulletin de la Société préhistorique française, 66(7), 197. https://doi.org/10.3406/bspf.1969.10404

Borradaile, G. J., Kissin, S. A., Stewart, J. D., Ross, W. A., \& Werner, T. (1993). Magnetic and Optical Methods for Detecting the Heat Treatment of Chert. Journal of Archaeological Science, 20(1), 5766.

Brenet, M., Guégan, S., Claud, É., Mesa, M., \& Pasquet, V. (2018). The Late Solutrean open-air site of Landry (Aquitaine, France). A preliminary spatio-temporal analysis. Quaternary International, 498, 30-50. https://doi.org/10.1016/j.quaint.2017.06.038 
Brown, K. S., Marean, C. W., Herries, A. I. R., Jacobs, Z., Tribolo, C., Braun, D., et al. (2009). Fire As an Engineering Tool of Early Modern Humans. Science, 325(5942), 859-862.

https://doi.org/10.1126/science.1175028

Collins, M. B. (1973). Observations on the thermal treatment of chert in the Solutrean of Laugerie Haute, France. Proceedings of the Prehistoric Society, 39, 461-466. https://doi.org/10.1017/S0079497X00011774

Collins, M. B., \& Fenwick, J. M. (1974). Heat Treating of Chert: Methods of Interpretation and Their Application. Plains Anthropologist, 19(64), 134-145. https://doi.org/10.1080/2052546.1974.11908696

Crabtree, D. E., \& Butler, B. R. (1964). Notes on Experiment in Flint Knapping: 1 Heat Treatment of Silica Materials. Tebiwa, 7, 1-6.

Delagnes, A., Schmidt, P., Douze, K., Wurz, S., Bellot-Gurlet, L., Conard, N. J., et al. (2016). Early Evidence for the Extensive Heat Treatment of Silcrete in the Howiesons Poort at Klipdrift Shelter (Layer PBD, 65 ka), South Africa. PLOS ONE, 11(10), e0163874. https://doi.org/10.1371/journal.pone.0163874

Delvigne, V. (2016, February 15). Georessources and techno cultural expressions in the South of the French Massif Central during the Upper Palaeolithic : determinism and choices.

Domanski, M., \& Webb, J. A. (1992). Effect of Heat Treatment on Siliceous Rocks Used in Prehistoric Lithic Technology. journal of archaeological science, 19(6), 601-614.

Domański, M., Webb, J., Glaisher, R., Gurba, J., Libera, J., \& Zakościelna, A. (2009). Heat treatment of Polish flints. Journal of Archaeological Science, 36(7), 1400-1408. https://doi.org/10.1016/i.jas.2009.02.002

Fernandes, P., Morala, A., Schmidt, P., Séronie-Vivien, Turq, A. (2012). Le silex du Bergeracois : état de la question, in: Bertran, P., Lenoble, A. (Eds.), Quaternaire continental d'Aquitaine : un point sur les travaux récents. Excursion AFEQ - ASF en Aquitaine du 30 mai au 01 juin 2012, L'imprimerie centrale de l'université de Bordeaux 1, 22-33.

Flenniken, J. J., \& Garrison, E. G. (1975). Thermally Altered Novaculite and Stone Tool Manufacturing Techniques. Journal of Field Archaeology, 2(1/2), 125. https://doi.org/10.2307/529623

Gibaja, J. F., \& Clemente, I. (1997). El tratamiento térmico del sílex y sus repercusiones en la determinación de los rastros de uso. Algunos ejemplos del neolitíco en Cataluña. Revista d'Arqueologia de Ponent, (7), pp 153-159.

Inizan, M.-L., Roche, H., \& Tixier, J. (1976). Avantage d'un traitement thermique pour la taille des roches siliceuses. Quaternaria, $X I X, 1-18$.

Key, A. J. M., Pargeter, J., \& Schmidt, P. (2020). Heat treatment significantly increases the sharpness of silcrete stone tools. Archaeometry. https://doi.org/10.1111/arcm.12619. Accessed 13 January 2021

Léa, V., Roque-Rosell, J., Binder, D., Sciau, Ph., Pelegrin, J., Regert, M., et al. (2012). Craft specialization and exchanges during the southern Chassey culture: an integrated archaeological and material sciences approach (Vol. 5, pp. 119-129). Presented at the Exchange of raw materials, products and ideas in the Western Mediterranean VII-III millennium BC: Colloque international Networks in the Neolithic, 02-04 Fév. 2011, Barcelone (Espagne): Revista Rubricatum.

Lechevalier, M., \& Inizan, M.-L. (1996). Deux traditions techniques de la pierre taillée dans le souscontinent indo-pakistanais : le débitage par pression et le traitement thermique. Paléorient, 22(1), 145-152. https://doi.org/10.3406/paleo.1996.4631 
Masson, A. (1981). Pétroarchéologie des roches siliceuses: intéret en Préhistoire (Unpublished Ph.d dissertation). Université Claude Bernard, Lyon, France.

Melcher, C. L., \& Zimmerman, D. W. (1977). Thermoluminescent determination of Prehistoric heat treatment of chert artifacts. Science, 197, 1359-1362.

Morala, A. (2017). Les silicifications des bassins versants de la Dordogne et de la Vézère: évaluation des ressources lithologiques et implications archéologiques (Musée National de Préhistoire.).

Purdy, B. A., \& Brooks, H. K. (1971). Thermal alteration of silica minerals: an archeological approach. Science, 173(3994), 322-325. https://doi.org/10.1126/science.173.3994.322

Santaniello, F., Grimaldi, S., Pedrotti, A., \& Gialanella, S. (2015). First evidence of heat treatment during the early Neolithic in northeastern Italy. Quaternary International, 1-10.

Santaniello, F., Berloffa, A., Grimaldi, S., Maffei, S., Pedrotti, A., and Gialanella, S., 2021, Density measurements as a non-destructive approach to investigate the heat treatment of siliceous lithic artefacts, Journal of Cultural Heritage, 47, 117-22.

Schindler, D. L., Hatch, J. W., Hay, C., \& Bradt, R. (1982). Aboriginal Thermal Alteration of a Central Pennsylvania Jasper: Analytical and Behavioral Implications. American Antiquity, 47(3), 526.

Schmidt, P. (2014). What causes failure (overheating) during lithic heat treatment? Archaeological and Anthropological Sciences, 6(2), 107-112. https://doi.org/10.1007/s12520-013-0162-3

Schmidt, P. (2019). How reliable is the visual identification of heat treatment on silcrete? A quantitative verification with a new method. Archaeological and Anthropological Sciences, 11(2), 713-726. https://doi.org/10.1007/s12520-017-0566-6

Schmidt, P. (2020). Heat Treatment. In Oxford Research Encyclopedia of Anthropology. Oxford University Press. https://doi.org/10.1093/acrefore/9780190854584.013.45

Schmidt, P., Badou, A., \& Fröhlich, F. (2011). Detailed FT near-infrared study of the behaviour of water and hydroxyl in sedimentary length-fast chalcedony, SiO2, upon heat treatment. Spectrochimica Acta Part A: Molecular and Biomolecular Spectroscopy, 81(1), 552-559.

Schmidt, P., Bellot-Gurlet, L., \& Floss, H. (2018). The unique Solutrean laurel-leaf points of Volgu: heat-treated or not? Antiquity, 92(363), 587-602. https://doi.org/10.15184/aqy.2018.87

Schmidt, P., Buck, G., Berthold, C., Lauer, C., \& Nickel, K. G. (2019). The mechanical properties of heat-treated rocks: a comparison between chert and silcrete. Archaeological and Anthropological Sciences, 11(6), 2489-2506. https://doi.org/10.1007/s12520-018-0710-y

Schmidt, P., \& Hiscock, P. (2020). The antiquity of Australian silcrete heat treatment: Lake Mungo and the Willandra Lakes. Journal of Human Evolution, 142, 102744. https://doi.org/10.1016/i.jhevol.2020.102744

Schmidt, P., Léa, V., Sciau, Ph., \& Fröhlich, F. (2013). Detecting and Quantifying Heat Treatment of Flint and Other Silica Rocks: A New Non-Destructive Method Applied to Heat-Treated Flint from the Neolithic Chassey Culture, Southern France. Archaeometry, 55(5), 794-805. https://doi.org/10.1111/j.1475-4754.2012.00712.x

Schmidt, P., Masse, S., Laurent, G., Slodczyk, A., Le Bourhis, E., Perrenoud, C., et al. (2012). Crystallographic and structural transformations of sedimentary chalcedony in flint upon heat treatment. Journal of Archaeological Science, 39, 135-144. https://doi.org/10.1016/j.jas.2011.09.012

Schmidt, P., Bellot-gurlet, L., \& Paris, C. (2015). The investment in time needed for heat treatment of flint and chert. Archaeological \& Anthropological Sciences, 1-10. 
Schmidt, P., Spinelli Sanchez, O., \& Kind, C.-J. (2017). Stone heat treatment in the Early Mesolithic of southwestern Germany: Interpretation and identification. PLOS ONE, 12(12), e0188576. https://doi.org/10.1371/journal.pone.0188576

Schmidt, P., Stynder, D., Conard, N. J., \& Parkington, J. E. (2020). When was silcrete heat treatment invented in South Africa? Palgrave Communications, 6(1), 1-10. https://doi.org/10.1057/s41599$\underline{020-0454-z}$

Schmidt, P., \& Morala, A. (2018). First Insights into the Technique Used for Heat Treatment of Chert at the Solutrean Site of Laugerie-Haute, France: The Technique Used for Heat Treatment at Solutrean Site of Laugerie-Haute. Archaeometry, 60(5), 885-897. https://doi.org/10.1111/arcm.12358

Schmidt, P., \& Morala, A. (2020). Are We Missing out on Half of All Heat-treated Pieces in the Solutrean? Lithic Technology, 45(1), 48-58. https://doi.org/10.1080/01977261.2019.1695076

Smith, P. E. L. (1966). Le Solutréen en France. impr. Delmas.

Tiffagom, M. (1998). Témoignages d'un traitement thermique des feuilles de laurier dans le Solutréen supérieur de la grotte du Parpalló (Gandia, Espagne). Paléo, 10(1), 147-161. https://doi.org/10.3406/pal.1998.1134

Tiffagom, M. (2006). De la pierre à l'Homme : essai sur une paléoantropologie solutréenne (thesis). Université de Liège.

Torchy, L. (2013, September). From upstream to downstream : function and management of lithic productions in exchange networks of southern Chassey culture (Unpublished Ph.d thesis). Université Toulouse le Mirail. Retrieved from https://tel.archives-ouvertes.fr/tel-01124208

Toyoda, S., Ikeya, M., Dunnell, R. C., \& McCutcheon, P. T. (1993). The use of electron spin resonance (ESR) for the determination of prehistoric lithic heat treatment. Applied Radiation and Isotopes, 44(1-2), 227-231.

Turq, A. (2000). Les ressources en matières premières lithiques. Paléo, 2(1), 98-141. https://doi.org/10.3406/pal.2000.1266

Turq, A., \& Morala, A. (2013). Inventaire des silicifications du Quercy, de ses marges et des marqueurs lithologiques du nord-est aquitain: synthèse des données. In Modalité d'occupation et exploitation des milieux au Paléolthique dans le Sud-Ouest de la France: l'exemple du Quercy (Vol. 4, pp. 159-180). Presented at the XVe Congrés mondial de I'UISPP, Lisbonne: Paléo.

Weiner, S., Brumfeld, V., Marder, O., \& Barzilai, O. (2015). Heating of flint debitage from Upper Palaeolithic contexts at Manot Cave, Israel: changes in atomic organization due to heating using infrared spectroscopy. Journal of Archaeological Science, 54, 45-53. https://doi.org/10.1016/i.jas.2014.11.023

Wilke, P. J., Flenniken, J. J., \& Ozbun, T. L. (1991). Clovis Technology at the Anzick Site, Montana. Journal of California and Great Basin Anthropology, 13(2), 242-272. 
Figure 1. Bifacial tools and end-scraper from Laugerie Haute West analyzed by IR spectroscopy. $n^{\circ} 1,3,6,8$ : Heat-treated samples with gloss contrast; $n^{\circ} 2,4,7$ : samples without clear indicator of heat treatment (possible gloss surface) $n^{\circ} 2,4,7$; and with no macroscopic traces: $n^{\circ} 5$ (photos Ph. Jugie, MNP, Les Eyzies; DAO and drawings J. Bachellerie)

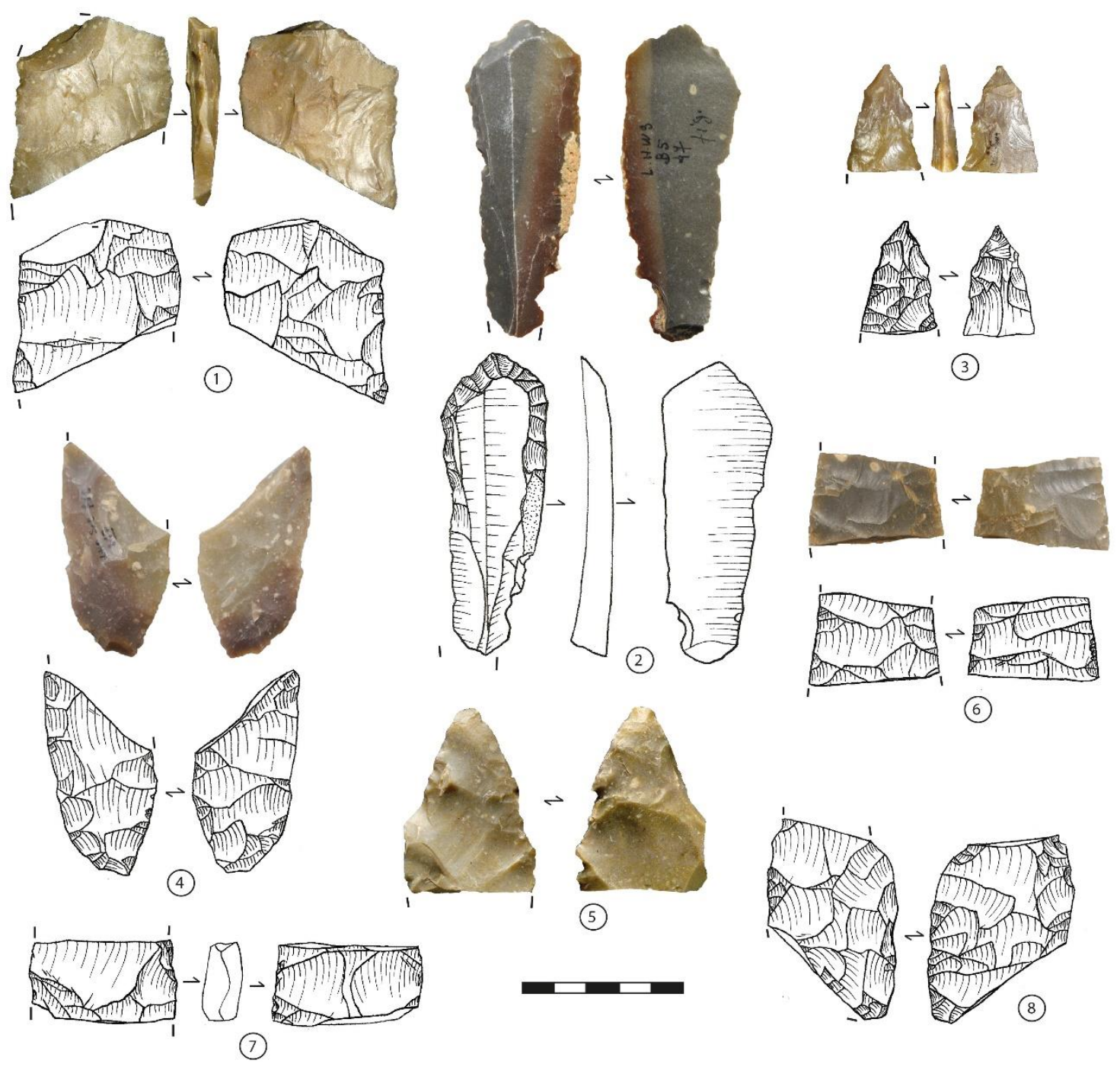


Figure 2. 2D and 3D representations of surface data files measured on ventral faces of experimentally heat-treated reference samples, produced by our laser-scanning microscope. (a) Unheated sample; (b) sample heated to $200^{\circ} \mathrm{C}$; (c) sample heated to $300^{\circ} \mathrm{C}$; (d) sample heated to $400^{\circ} \mathrm{C}$. All these samples are extracted from the same chert block. The different magnitude of the surface roughness at the different heating stages is best appreciated by comparing the different $Z$ scales in the lower $3 \mathrm{D}$ representations.
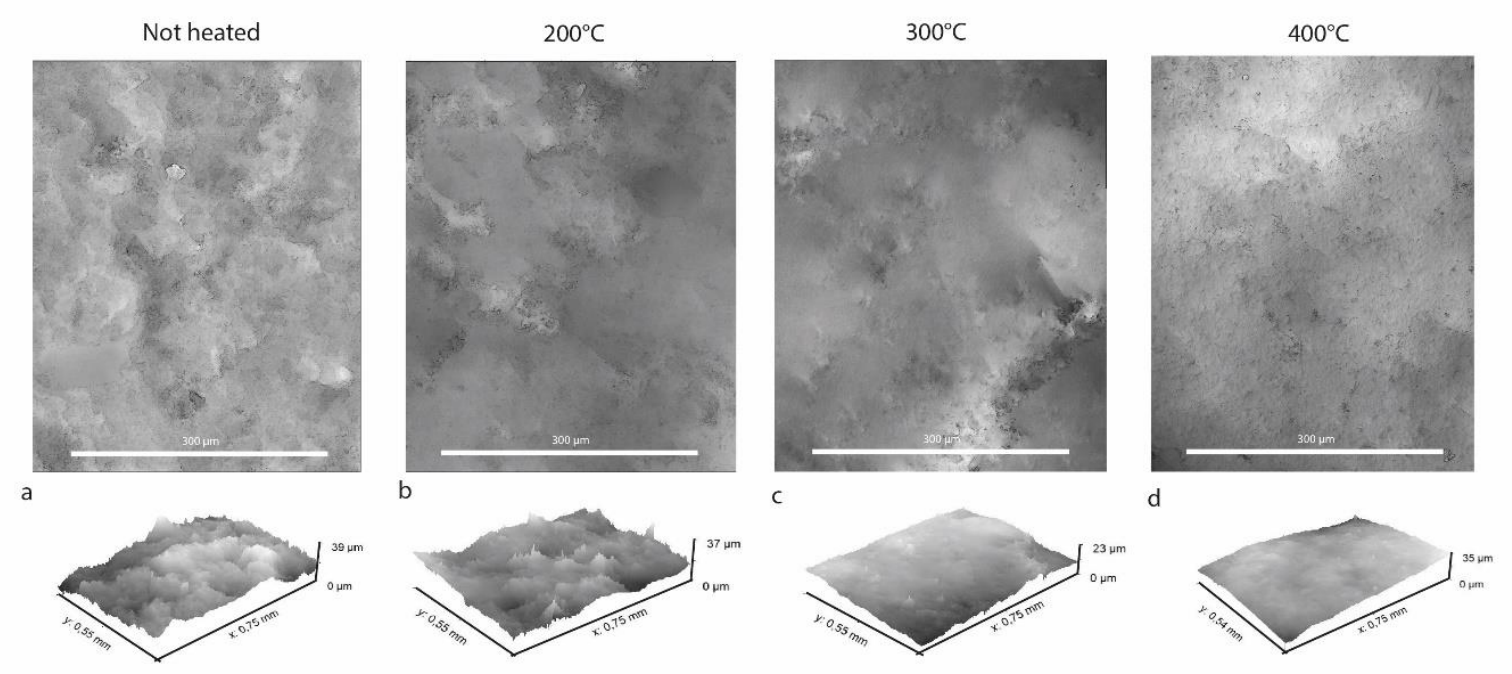

Figure 3. Comparison of $4545 / 4469 \mathrm{~cm}^{-1}$ ratios from (a) experimentally heat-treated reference samples and (b) archaeological samples. Descriptions Not heated, Heat-treated and Test in the inlet are macroscopic observations made before the IR analyses.

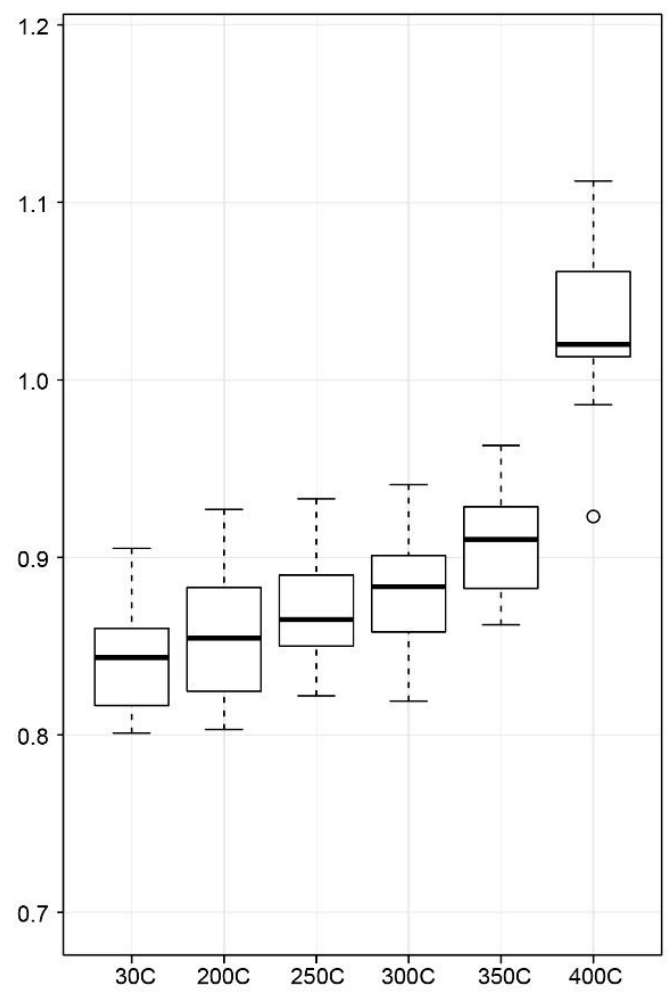

a

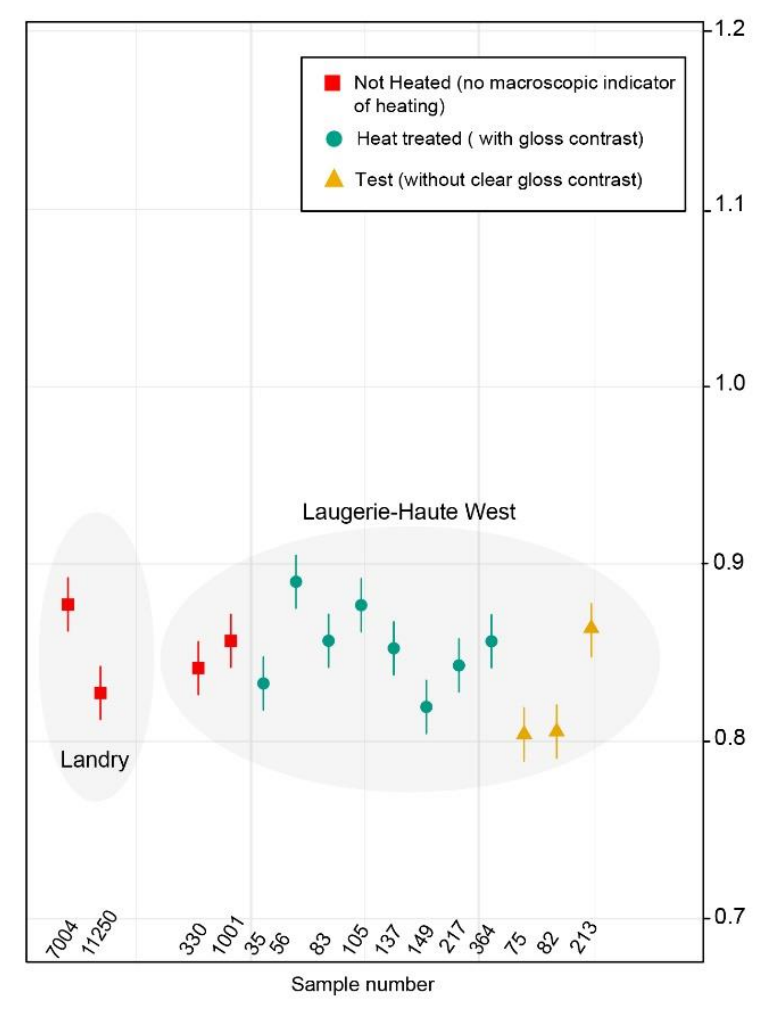

b 
Figure 4. (a) Thermal evolution of surface roughness of Bergerac chert established from fresh flakes removed from three chert blocks that were successively heated to $200,250,250,300,350$ and $400^{\circ} \mathrm{C}$ (flakes removed after each temperature step). (b) Comparison of roughness values obtained from 14 Solutrean artefacts from Laugerie Haute West: two without any macroscopic traces of heating (in orange), three with gloss contrast documenting heat treatment (in green), and nine without clear evidence of heating (in purple).

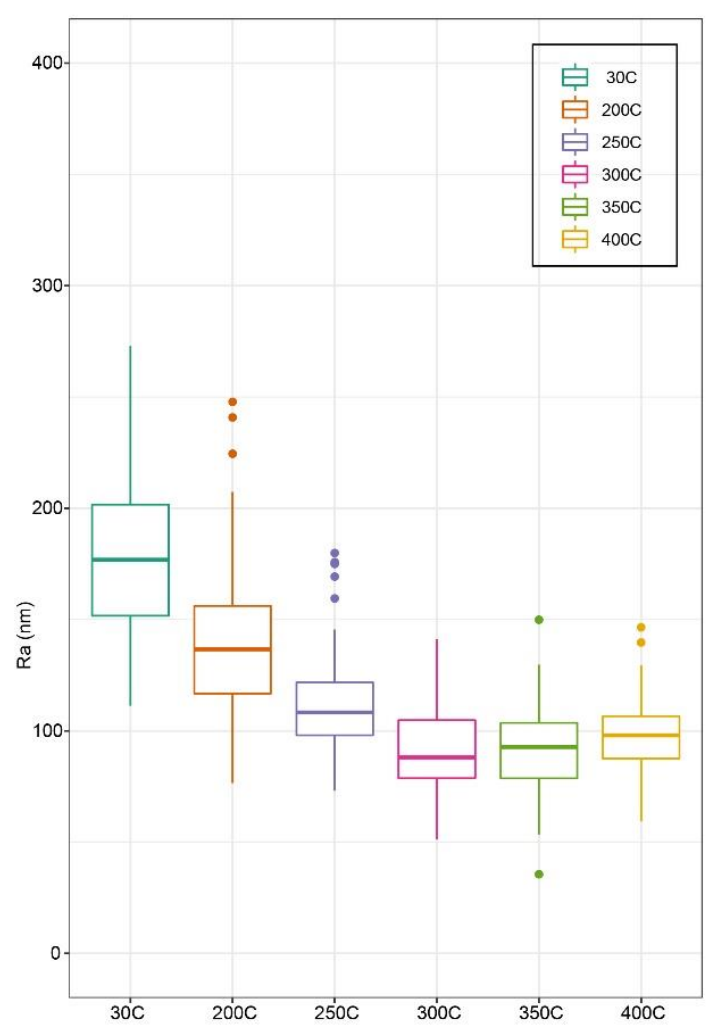

a

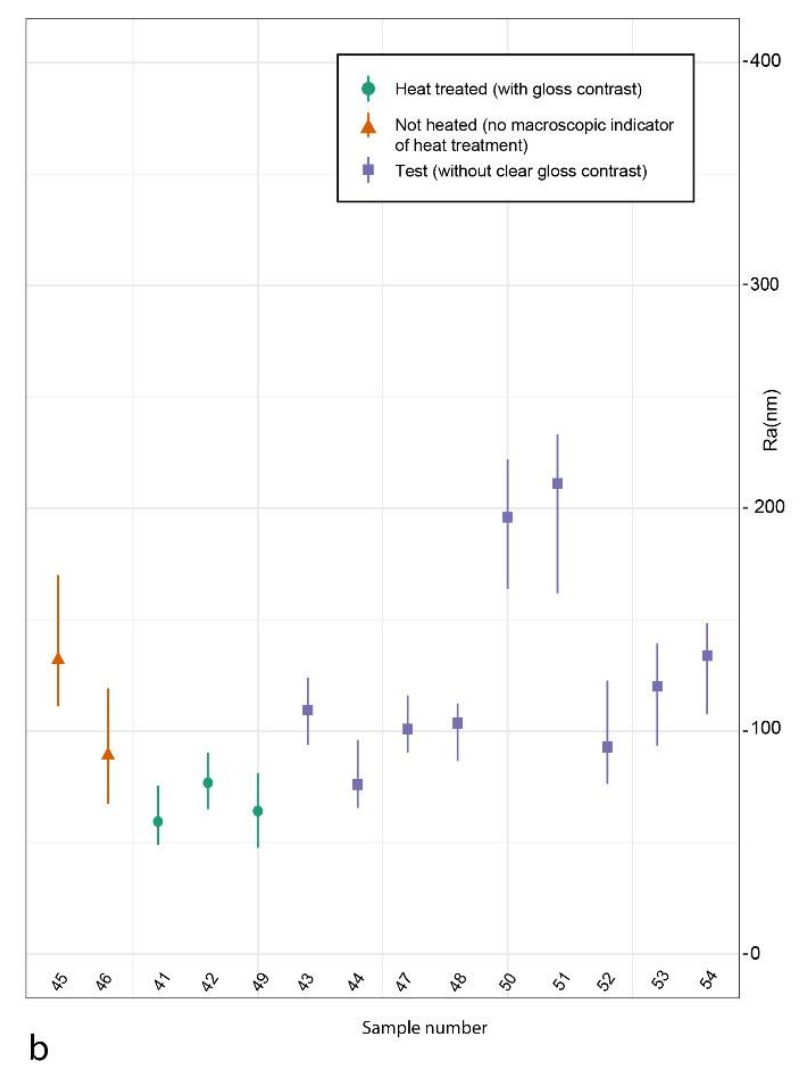


Table S1. Ra values obtained from each cut-off profiles $(0.010 \mu \mathrm{m})$.

\begin{tabular}{|c|c|c|c|c|c|c|c|c|c|c|c|c|c|c|c|c|c|}
\hline \multicolumn{6}{|c|}{ Block A } & \multicolumn{6}{|c|}{ Block B } & \multicolumn{5}{|c|}{ Block C } & \\
\hline Temperature & \multicolumn{5}{|c|}{$\mathrm{Ra}(\mathrm{nm})$} & Temperature & \multicolumn{5}{|c|}{$\mathrm{Ra}(\mathrm{nm})$} & Temperature & \multicolumn{4}{|c|}{$\mathrm{Ra}(\mathrm{nm})$} & \\
\hline \multirow{5}{*}{$\begin{array}{l}30 \mathrm{C} \text { (Not } \\
\text { heated) }\end{array}$} & 208,2 & 195,4 & 183,2 & 133,2 & 158,7 & & 172,6 & 152,6 & 112,3 & 125,4 & 158,1 & & 230,9 & 158,9 & 212,9 & 219,9 & 139,9 \\
\hline & 187,8 & 190,2 & 246,7 & 165,2 & 148,1 & & 178 & 132,7 & 128,1 & 150,8 & 155,8 & & 208,3 & 116,7 & 255,8 & 213,9 & 142 \\
\hline & 187,2 & 163,8 & 213,5 & 182,9 & 134,7 & & 155,9 & 145,4 & 142,2 & 186,7 & 162,4 & & 179,8 & 184,4 & 184,9 & 206,2 & 135 \\
\hline & 205,1 & 196,1 & 220,5 & 199,9 & 121,5 & & 196,9 & 161,6 & 111,3 & 212,2 & 140,6 & & 207,2 & 162,6 & 203,4 & 199,1 & 164 \\
\hline & 221,5 & 176,9 & 214,8 & 239,9 & 193,4 & $30 \mathrm{C}$ & 171,6 & 148,9 & 123 & 158,1 & 189,5 & $30 \mathrm{C}$ & 191,1 & 158,6 & 272,9 & 165,4 & 171,5 \\
\hline \multirow[b]{5}{*}{$200 \mathrm{C}$} & 192,5 & 127,5 & 136,6 & 122,7 & 136,2 & & 148,7 & 169,7 & 113,3 & 149,8 & 144 & & 143,3 & 107,6 & 130,8 & 155,4 & 151,5 \\
\hline & 207,3 & 140,7 & 170,5 & 141,5 & 194,5 & & 125,7 & 119,9 & 127,3 & 92,94 & 96,65 & & 120,3 & 125,8 & 143,8 & 247,8 & 150 \\
\hline & 184,8 & 150,3 & 157,3 & 153,7 & 224,5 & & 108,7 & 121 & 133,7 & 107,8 & 76,6 & & 123,5 & 141,8 & 105,7 & 127,4 & 111,1 \\
\hline & 240,8 & 205,5 & 99,75 & 160,8 & 177,7 & & 88,46 & 157,9 & 137 & 95,81 & 113,5 & & 148 & 183,1 & 103,1 & 149,7 & 101,1 \\
\hline & 168,7 & 159,7 & 127,7 & 121,6 & 168,9 & $200 C$ & 124,4 & 130,9 & 156,9 & 83,72 & 106,8 & $200 \mathrm{C}$ & 146,9 & 143,8 & 107,1 & 128,6 & 107,8 \\
\hline \multirow[b]{5}{*}{$250 \mathrm{C}$} & 169,3 & 131,8 & 99,1 & 99,83 & 134,5 & & 105,8 & 142,4 & 108,9 & 109,4 & 179,9 & & 92,11 & 91,35 & 85,27 & 111,1 & 108,2 \\
\hline & 124,1 & 122 & 78,25 & 91,36 & 84,08 & & 96,13 & 108,3 & 101,3 & 103,6 & 116,3 & & 108,4 & 79,17 & 126,8 & 81,78 & 80,87 \\
\hline & 159,5 & 115,5 & 105,7 & 109,8 & 98,99 & & 125,6 & 110,9 & 103 & 138,3 & 132,3 & & 99,79 & 91,21 & 106,1 & 130,9 & 106,3 \\
\hline & 175,8 & 175 & 103,3 & 107,8 & 97,3 & & 126,5 & 90,5 & 135 & 120,5 & 145,5 & & 98,74 & 85,07 & 121,6 & 93,77 & 112,9 \\
\hline & 116,8 & 115,9 & 76,44 & 120 & 100,3 & $250 \mathrm{C}$ & 112,5 & 104,3 & 118,1 & 112,9 & 135,7 & $250 \mathrm{C}$ & 73,11 & 92,4 & 90,87 & 107,2 & 120,7 \\
\hline \multirow[b]{5}{*}{$300 \mathrm{C}$} & 79,37 & 87,43 & 117,3 & 105,9 & 66,61 & & 79,3 & 98,16 & 117 & 91,16 & 112,9 & & 80,09 & 95,16 & 104,6 & 78,14 & 68,58 \\
\hline & 87,52 & 76,41 & 118,8 & 106,3 & 95,73 & & 141,1 & 66,26 & 93,1 & 101 & 107,1 & & 86,41 & 73,96 & 91,14 & 80,07 & 61,64 \\
\hline & 87,5 & 111,6 & 107,4 & 77,97 & 51,17 & & 80,03 & 87,55 & 84,63 & 83,68 & 99,4 & & 74,62 & 83,2 & 70,62 & 79,67 & 82,26 \\
\hline & 79,96 & 89,85 & 132,9 & 93,56 & 72,52 & & 120,3 & 102,4 & 88,06 & 70,98 & 104,9 & & 53,89 & 72,97 & 88,03 & 75,99 & 62,08 \\
\hline & 95,71 & 105,9 & 127,5 & 104,7 & 96,34 & $300 \mathrm{C}$ & 110,9 & 105,8 & 120,1 & 86,73 & 130,3 & $300 \mathrm{C}$ & 76,88 & 88,04 & 100,6 & 82,1 & 68,41 \\
\hline \multirow[b]{5}{*}{$350 \mathrm{C}$} & 98,54 & 108,7 & 74,83 & 87,09 & 98,72 & & 66,45 & 101,7 & 53,44 & 122,7 & 149,9 & \multirow[b]{5}{*}{$350 \mathrm{C}$} & 82,65 & 104,7 & 97,81 & 72,1 & 79,78 \\
\hline & 103,8 & 93,57 & 98,24 & 107,2 & 112,6 & & 78,59 & 92,17 & 65,67 & 105 & 98,56 & & 91,36 & 91,2 & 103,4 & 110,5 & 75,73 \\
\hline & 77,49 & 122,4 & 84,38 & 88,74 & 86,87 & & 65,34 & 106,2 & 58,32 & 115,1 & 94,03 & & 76,28 & 75,27 & 100,2 & 81,62 & 66,55 \\
\hline & 94,77 & 114,1 & 97,03 & 96,42 & 82,46 & & 97,17 & 113,1 & 65,44 & 115 & 95,09 & & 84,3 & 91,73 & 104,7 & 93,87 & 73,68 \\
\hline & 93,74 & 85,95 & 83,22 & 108,2 & 89,55 & $350 \mathrm{C}$ & 78,68 & 92,69 & 35,57 & 129,7 & 126,2 & & 75,54 & 76,92 & 102,7 & 91,3 & 66,63 \\
\hline \multirow[b]{5}{*}{$400 \mathrm{C}$} & 96,16 & 74,39 & 103,7 & 108,3 & 112,6 & \multirow[b]{5}{*}{$400 C$} & 59,58 & 101,7 & 61,06 & 92,28 & 94,62 & & & & & & \\
\hline & 106,7 & 93,43 & 103,2 & 114,7 & 139,7 & & 93,74 & 78,41 & 69,09 & 84,81 & 96,89 & & & & & & \\
\hline & 99,21 & 90,98 & 87,52 & 114,8 & 129,4 & & 114,4 & 101,6 & 75,85 & 106,4 & 100,9 & & & & & & \\
\hline & 79,63 & 104 & 87,6 & 120,6 & 98,02 & & 59,33 & 90,17 & 94,57 & 93,42 & 104 & & & & & & \\
\hline & 80,09 & 110,2 & 98 & 146,5 & 105,4 & & 108,3 & 101,8 & 73,48 & 76,15 & 114,1 & & & & & & \\
\hline
\end{tabular}


Table S2. Hydration ratio values obtained from four geological references blocks. The ratio are obtained by dividing component 1 by component 2 .

\begin{tabular}{|c|c|c|c|c|c|c|c|c|}
\hline & \multicolumn{2}{|c|}{ BLOCK D } & \multicolumn{2}{|c|}{ BLOCK E } & \multicolumn{2}{|c|}{ BLOCK G } & \multicolumn{2}{|c|}{ BLOCK F } \\
\hline TEMPERATURE & $\mathrm{n}$ & $\begin{array}{c}\text { hydration } \\
\text { ratio }\end{array}$ & $\mathrm{n}$ & $\begin{array}{l}\text { hydration } \\
\text { ratio }\end{array}$ & $\mathrm{n}$ & $\begin{array}{c}\text { hydration } \\
\text { ratio }\end{array}$ & $\mathrm{n}$ & $\begin{array}{c}\text { hydration } \\
\text { ratio }\end{array}$ \\
\hline \multirow{5}{*}{$\begin{array}{c}30^{\circ} \mathrm{C} \text { (Not } \\
\text { heated) }\end{array}$} & 1 & 0,88 & 31 & 0,856 & 61 & 0,805 & 91 & 0,901 \\
\hline & 2 & 0,859 & 32 & 0,861 & 62 & 0,801 & 92 & 0,826 \\
\hline & 3 & 0,869 & 33 & 0,905 & 63 & 0,801 & 93 & 0,839 \\
\hline & 4 & 0,852 & 34 & 0,85 & 64 & 0,802 & 94 & 0,839 \\
\hline & 5 & 0,838 & 35 & 0,848 & 65 & 0,807 & 95 & 0,836 \\
\hline \multirow[b]{5}{*}{$200^{\circ} \mathrm{C}$} & 6 & 0,889 & 36 & 0,855 & 66 & 0,808 & 96 & 0,854 \\
\hline & 7 & 0,862 & 37 & 0,905 & 67 & 0,813 & 97 & 0,874 \\
\hline & 8 & 0,871 & 38 & 0,841 & 68 & 0,82 & 98 & 0,835 \\
\hline & 9 & 0,899 & 39 & 0,877 & 69 & 0,806 & 99 & 0,829 \\
\hline & 10 & 0,829 & 40 & 0,927 & 70 & 0,803 & 100 & 0,891 \\
\hline \multirow[b]{5}{*}{$250^{\circ} \mathrm{C}$} & 11 & 0,892 & 41 & 0,849 & 71 & 0,826 & 101 & 0,891 \\
\hline & 12 & 0,879 & 42 & 0,867 & 72 & 0,822 & 102 & 0,895 \\
\hline & 13 & 0,896 & 43 & 0,863 & 73 & 0,836 & 103 & 0,933 \\
\hline & 14 & 0,869 & 44 & 0,86 & 74 & 0,84 & 104 & 0,889 \\
\hline & 15 & 0,856 & 45 & 0,853 & 75 & 0,851 & 105 & 0,869 \\
\hline \multirow[b]{5}{*}{$300^{\circ} \mathrm{C}$} & 16 & 0,898 & 46 & 0,905 & 76 & 0,85 & 106 & 0,869 \\
\hline & 17 & 0,889 & 47 & 0,911 & 77 & 0,839 & 107 & 0,878 \\
\hline & 18 & 0,941 & 48 & 0,889 & 78 & 0,819 & 108 & 0,866 \\
\hline & 19 & 0,866 & 49 & 0,898 & 79 & 0,83 & 109 & 0,927 \\
\hline & 20 & 0,878 & 50 & 0,898 & 80 & 0,904 & 110 & 0,848 \\
\hline \multirow[b]{5}{*}{$350^{\circ} \mathrm{C}$} & 21 & 0,876 & 51 & 0,94 & 81 & 0,872 & 111 & 0,908 \\
\hline & 22 & 0,947 & 52 & 0,963 & 82 & 0,862 & 112 & 0,92 \\
\hline & 23 & 0,933 & 53 & 0,912 & 83 & 0,883 & 113 & 0,891 \\
\hline & 24 & 0,949 & 54 & 0,924 & 84 & 0,882 & 114 & 0,922 \\
\hline & 25 & 0,919 & 55 & 0,902 & 85 & 0,876 & 115 & 0,908 \\
\hline \multirow[b]{5}{*}{$400^{\circ} \mathrm{C}$} & 26 & 1,016 & 56 & 1,016 & 86 & 1,064 & 116 & 1,058 \\
\hline & 27 & 1,019 & 57 & 1,02 & 87 & 1,112 & 117 & 1,079 \\
\hline & 28 & 1,055 & 58 & 0,923 & 88 & 0,986 & 118 & 1,049 \\
\hline & 29 & 1,011 & 59 & 1,001 & 89 & 1,035 & 119 & 1,093 \\
\hline & 30 & 1,015 & 60 & 1,006 & 90 & 1,076 & & \\
\hline
\end{tabular}


Table 1. Hydration ratio values $4545 / 4469 \mathrm{~cm}-1$ obtained on sixteen archaeological samples.

\begin{tabular}{|c|c|c|c|c|c|}
\hline $\begin{array}{l}\text { Sample } \\
\text { number }\end{array}$ & Site & Typology & $\begin{array}{c}\text { Indicators of heat } \\
\text { treatment }\end{array}$ & $\begin{array}{c}\text { Hydration } \\
\text { ratio ( } \pm \\
0.01)\end{array}$ & $\begin{array}{l}\text { RESULTS (combining } \\
\text { IR results and } \\
\text { macroscopic } \\
\text { observations) }\end{array}$ \\
\hline 7004 & Landry (Dordogne) & End-scraper & - & 0,8774 & not heated ? \\
\hline 11250 & Landry (Dordogne) & End-scraper & - & 0,8275 & not heated? \\
\hline 330 & Laugerie-Haute West (Dordogne) & End-scraper & - & 0,8415 & not heated? \\
\hline 1001 & Laugerie-Haute West (Dordogne) & Laurel leaf & - & 0,8569 & not heated? \\
\hline 35 & Laugerie-Haute West (Dordogne) & Laurel leaf & gloss contrast & 0,8329 & $\begin{array}{l}\text { heated (around } 200- \\
300^{\circ} \mathrm{C} \text { ) }\end{array}$ \\
\hline 56 & Laugerie-Haute West (Dordogne) & Laurel leaf & gloss contrast & 0,8902 & $\begin{array}{l}\text { heated (around } 200- \\
350^{\circ} \mathrm{C} \text { ) }\end{array}$ \\
\hline 83 & Laugerie-Haute West (Dordogne) & Shouldered point & gloss contrast & 0,8569 & $\begin{array}{c}\text { heated (around } 200- \\
350^{\circ} \mathrm{C} \text { ) }\end{array}$ \\
\hline 105 & Laugerie-Haute West (Dordogne) & Laurel leaf & gloss contrast & 0,877 & $\begin{array}{l}\text { heated (around } 200- \\
350^{\circ} \mathrm{C} \text { ) }\end{array}$ \\
\hline 137 & Laugerie-Haute West (Dordogne) & Laurel leaf & gloss contrast & 0,8527 & $\begin{array}{l}\text { heated (around 200- } \\
\qquad 350^{\circ} \mathrm{C} \text { ) }\end{array}$ \\
\hline 149 & Laugerie-Haute West (Dordogne) & End-scraper & gloss contrast & 0,8197 & $\begin{array}{l}\text { heated (around } 200- \\
300^{\circ} \mathrm{C} \text { ) }\end{array}$ \\
\hline 217 & Laugerie-Haute West (Dordogne) & Laurel leaf & gloss contrast & 0,843 & $\begin{array}{l}\text { heated (around } 200- \\
300^{\circ} \mathrm{C} \text { ) }\end{array}$ \\
\hline 364 & Laugerie-Haute West (Dordogne) & Shouldered point & gloss contrast & 0,8566 & $\begin{array}{c}\text { heated (around } 200- \\
350^{\circ} \mathrm{C} \text { ) } \\
\end{array}$ \\
\hline 75 & Laugerie-Haute West (Dordogne) & Bifacial point & glossy surface? & 0,8042 & $?$ \\
\hline 82 & Laugerie-Haute West (Dordogne) & Shouldered point & glossy surface? & 0,8057 & $?$ \\
\hline 213 & Laugerie-Haute West (Dordogne) & bifacial point & glossy surface? & 0,8629 & $?$ \\
\hline
\end{tabular}


Table 2. Ra measurments obtained on fourteen artefacts from Laugerie Haute West (Five profiles per sample, with a cut-off of $0.01 \mu \mathrm{m}$ ). The last two columns compare the results obtained in our study with those achieved in 2019 by IR spectroscopy (Schmidt and Morala 2020).

\begin{tabular}{|c|c|c|c|c|c|c|c|c|}
\hline $\begin{array}{l}\text { Sample } \\
\text { number }\end{array}$ & Site & Typology & $\begin{array}{c}\text { Indicators of } \\
\text { heat } \\
\text { treatment }\end{array}$ & \multicolumn{2}{|c|}{$\begin{array}{c}\text { Hydratation ratio (Ra, cut off } \\
0.1 \text { ) }\end{array}$} & $\begin{array}{l}\text { Average Ra } \\
\text { per sample }\end{array}$ & \multirow{2}{*}{$\begin{array}{c}\text { Result } \\
\text { Not Heated }\end{array}$} & \multirow{2}{*}{$\begin{array}{c}\begin{array}{c}\text { Result from } \\
\text { IR (Schmidt } \\
\text { and Morala } \\
\text { 2020) }\end{array} \\
\text { Not Heated }\end{array}$} \\
\hline 45 & $\begin{array}{c}\text { Laugerie- } \\
\text { Haute West }\end{array}$ & End-scrapper & - & $\begin{array}{l}122,1 \\
113,3 \\
111,1 \\
\end{array}$ & $\begin{array}{l}143,8 \\
170,1\end{array}$ & 132,08 & & \\
\hline 46 & $\begin{array}{c}\text { Laugerie- } \\
\text { Haute West }\end{array}$ & End-scrapper & - & $\begin{array}{l}67,2 \\
94,9 \\
74,8 \\
\end{array}$ & $\begin{array}{c}119,2 \\
90,4\end{array}$ & 89,296 & $?$ & Not Heated \\
\hline 41 & $\begin{array}{c}\text { Laugerie- } \\
\text { Haute West }\end{array}$ & Flake & Gloss contrast & $\begin{array}{l}63,5 \\
53,9 \\
48,9 \\
\end{array}$ & $\begin{array}{l}75,7 \\
55,2\end{array}$ & 59,436 & Heated & Heated \\
\hline 42 & $\begin{array}{c}\text { Laugerie- } \\
\text { Haute West }\end{array}$ & Laurel leaf & Gloss contrast & $\begin{array}{c}77,3 \\
78,4 \\
73 \\
\end{array}$ & $\begin{array}{l}90,5 \\
65,1\end{array}$ & 76,846 & Heated & Heated \\
\hline 49 & $\begin{array}{c}\text { Laugerie- } \\
\text { Haute West } \\
\end{array}$ & Laurel leaf & Gloss contrast & $\begin{array}{l}47,8 \\
64,8 \\
52,2 \\
\end{array}$ & $\begin{array}{l}74,9 \\
81,2\end{array}$ & 64,156 & Heated & Heated \\
\hline 43 & $\begin{array}{c}\text { Laugerie- } \\
\text { Haute West }\end{array}$ & Laurel leaf & $\begin{array}{c}\text { glossy surface } \\
?\end{array}$ & $\begin{array}{c}93,8 \\
120,8 \\
102,6 \\
\end{array}$ & $\begin{array}{l}105,8 \\
124,1\end{array}$ & 109,428 & Not Heated & Not Heated \\
\hline 44 & $\begin{array}{c}\text { Laugerie- } \\
\text { Haute West }\end{array}$ & Laurel leaf & $\begin{array}{c}\text { glossy surface } \\
? \\
\end{array}$ & $\begin{array}{c}72 \\
78,5 \\
68,4 \\
\end{array}$ & $\begin{array}{l}65,6 \\
96,1\end{array}$ & 76,116 & Heated & Not Heated \\
\hline 47 & $\begin{array}{c}\text { Laugerie- } \\
\text { Haute West }\end{array}$ & Laurel leaf & $\begin{array}{c}\text { glossy surface } \\
?\end{array}$ & $\begin{array}{c}90,5 \\
104,7 \\
97,3 \\
\end{array}$ & $\begin{array}{l}96,3 \\
116\end{array}$ & 100,954 & $?$ & Not Heated \\
\hline 48 & $\begin{array}{c}\text { Laugerie- } \\
\text { Haute West }\end{array}$ & Laurel leaf & $\begin{array}{c}\text { glossy surface } \\
?\end{array}$ & $\begin{array}{c}86,6 \\
105,6 \\
105,7 \\
\end{array}$ & $\begin{array}{l}112,5 \\
107,6\end{array}$ & 103,598 & $?$ & $?$ \\
\hline 50 & $\begin{array}{l}\text { Laugerie- } \\
\text { Haute West }\end{array}$ & Laurel leaf & $\begin{array}{c}\text { glossy surface } \\
?\end{array}$ & $\begin{array}{l}163,9 \\
205,9 \\
188,9\end{array}$ & $\begin{array}{l}221,9 \\
199,3\end{array}$ & 195,98 & Not Heated & Heated \\
\hline 51 & $\begin{array}{c}\text { Laugerie- } \\
\text { Haute West }\end{array}$ & Laurel leaf & $\begin{array}{c}\text { glossy surface } \\
?\end{array}$ & $\begin{array}{c}233,1 \\
209 \\
162 \\
\end{array}$ & $\begin{array}{l}218,2 \\
233,3\end{array}$ & 211,12 & Not Heated & Not Heated \\
\hline 52 & $\begin{array}{c}\text { Laugerie- } \\
\text { Haute West }\end{array}$ & Laurel leaf & $\begin{array}{c}\text { glossy surface } \\
?\end{array}$ & $\begin{array}{l}87,3 \\
76,4 \\
83,9 \\
\end{array}$ & $\begin{array}{c}94,1 \\
122,7\end{array}$ & 92,874 & $?$ & Not Heated \\
\hline 53 & $\begin{array}{c}\text { Laugerie- } \\
\text { Haute West }\end{array}$ & Laurel leaf & $\begin{array}{c}\text { glossy surface } \\
?\end{array}$ & $\begin{array}{c}93,3 \\
139,5 \\
120,5 \\
\end{array}$ & $\begin{array}{l}108,1 \\
139,3\end{array}$ & 120,136 & Not Heated & Not Heated \\
\hline 54 & $\begin{array}{l}\text { Laugerie- } \\
\text { Haute West }\end{array}$ & Laurel leaf & $\begin{array}{c}\text { glossy surface } \\
?\end{array}$ & $\begin{array}{c}147,6 \\
107,6 \\
133\end{array}$ & $\begin{array}{l}132,7 \\
148,5\end{array}$ & 133,88 & Not Heated & Not Heated \\
\hline
\end{tabular}

